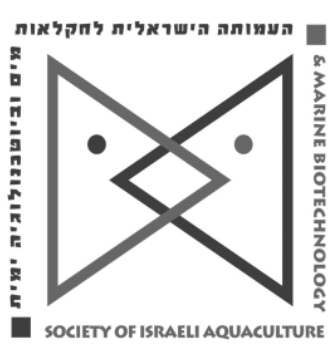

The IJA appears exclusively as a peer-reviewed on-line open-access journal at http://www.siamb.org.il. To read papers free of charge, please register online at registration form.

Sale of $I J A$ papers is strictly forbidden.

\title{
Dietary Effect of Probiotic Bacteria, Bacillus amyloliquefaciens-JFP2 on Growth and Innate Immune Response in Rock Bream Oplegnathus fasciatus, Challenged with Streptococcus iniae
}

\author{
Dong-Hwi Kim ${ }^{1 \dagger}$, Dharaneedharan Subramanian ${ }^{1 \dagger}$, Moon-Soo \\ Heo $^{1 *}$ \\ ${ }^{1}$ Marine Applied Microbes and Aquatic Organism Disease Control Lab, \\ Department of Aquatic Biomedical Sciences, School of Marine Life \\ Sciences, Jeju National University, Jeju 63243, Republic of Korea.
}

Keywords: probiotic feed; B. amyloliquefaciens; Jeju Island; Oplegnathus fasciatus; rock bream

\begin{abstract}
The present study was conducted to evaluate the use of Bacillus amyloliquefaciens as a probiotic source in the diet of rock bream, Oplegnathus fasciatus. A total of 210 fingerlings $(25.4 \pm 0.13 \mathrm{~g})$ were divided into two groups, three replicates each; control (C) and probiotic $(P)$ group $(35 \times 3=105$ fish per group). C group was fed a basal diet without probiotic while $P$ group was fed with $B$. amyloliquefaciens spores at a concentration of $1.4 \times 10^{6}$ colony-forming units per gram (CFU/g) of feed. After 90 days, $P$ group fish showed significant improvements in body weight (BW), weight gain (WG), specific growth rate (SGR) and food conversion ratio (FCR) when compared with $\mathrm{C}$ group fish. Also, in bi-weekly assessments, serum protein and glucose level showed a significant increase $(p<0.05)$ in probiotic fed fish compared with the control group. Similar increase in serum antioxidant and lysozyme activity was found in the probiotic fed fish group. However, there was a significant decrease in triglyceride and total cholesterol along with increased alanine aminotransferase (ALT) and aspartate amonotransferase (AST) levels in probiotic diet fed fish compared to the control. After seventy days the fish were challenged with Streptococcus iniae and mortality of the probiotic fed fish was significantly lower $(p<0.05)$ when compared with the control. These results demonstrate the benefit of incorporation of $B$. amyloliquefaciens as a feed supplement to improve the health status of Oplegnathus fasciatus challenged with Streptococcus iniae.
\end{abstract}

*Corresponding author: email: msheo@jejunu.ac.kr; Tel: +8264543473;

Fax: +82647563 .

t The authors contributed equally to this work. 


\section{Introduction}

Microbial pathogens can have a significantly negative effect on the progress of aquaculture (FAO, 2014). Outbreaks of disease, coupled with restricted use of chemical antibiotics, have increased the necessity to search for, and use other antibiotic alternatives. In the past two decades, use of probiotics in the prevention and management of fish diseases has received much interest. Probiotics are beneficial microbial cells that are commonly used as immune-modulators (Nwanna et al., 2014; Salminen et al., 1999). The supplementation of fish diets with probiotics modulate specific functions of the gut and immune system and enhance disease protection (Gullian et al., 2004; Nayak, 2010). The most commonly used probiotics in aquaculture are Bacillus sp., Lactobacillus sp., and Saccharomyces sp (Abdel-Tawwab et al., 2008; Aly et al., 2008; Pal et al., 2007).

Bacillus species are nonpathogenic aerobic gram-positive bacteria that are administrated orally to enhance gastro-intestinal microbial populations (Zhou et al., 2010; Ridha and Azad, 2012; Miao et al., 216). Most probiotic microbes are marketed as drug or foodstuffs and their safe application has been confirmed (Mayra-Makien \& Bigert, 1993). Efforts to use probiotic bacteria as biological control agents for fish diseases have increased due to shortage of effective and safe antibiotics (Bansemir et al., 2006). Though several studies have reported in vitro and in vivo influence of probiotics on different fish species, knowledge regarding the dietary effect of $B$. amyloliquefaciens on rock bream remains scant.

Rock bream, Oplegnathus fasciatus, is an economically important marine fish in East Asia. In 2012, its aquaculture production in Korea alone was approximately 650 metric tons (MOMAF, 2014). However, high mortality of both juvenile and adult rock bream occurs in early summer when water temperatures increase to $16-19^{\circ} \mathrm{C}$ ( $\mathrm{Kim}$ et al, 2008). With growing interest in culture of this species, there has been an increase in the number of published studies on nutrition of $O$. fasciatus (Kang et al., 1998; Wang et al., 2003; Kim et al., 2008; Hwang et al., 2013; Kim et al., 2013a, 2013b) however there is little information on feeding and dietary additives that promote the health status of this species (Ko et al., 2008; Lim et al., 2013). The present study was conducted to investigate the dietary effects $B$. amyloliquefaciens-JFP2 on growth, feed consumption, and innate immune response in probiotic fed juvenile rock bream, Oplegnathus fasciatus challenged with Streptococcus iniae.

\section{Materials and methods}

Fish. Healthy cultured rock bream, Oplegnathus fasciatus $(25.4 \pm 0.13 \mathrm{~g}, n=250)$ were obtained from a local fish farm in Jeju Island, Republic of Korea. The fish were transported and reared in a recirculating culture system in the Department of Aquatic Biomedical Science, Jeju National University. The recirculating culture system consisted of four $1000 \mathrm{~L}$ circular tanks and one $1000 \mathrm{~L}$ filter tank with continuous aeration and temperature control. Rearing tank water was partially replaced with sand filtered water once a week. The measured water quality parameters were: salinity $33 \pm 0.7 \mathrm{ppt}, \mathrm{pH}$ $7.5 \pm 0.6$, dissolved oxygen $8.4 \pm 0.6 \mathrm{mg} / \mathrm{L}$, ammonia $0.006 \mathrm{mg} / \mathrm{L}$, and photoperiod $14 \mathrm{~h}$ light: $10 \mathrm{~h}$ dark cycle. Fish were fed with a basal diet ad libitum twice a day at 09:00 and 15:00 $\mathrm{h}$ at a rate of $5 \%$ of their body weight (Table 1 ). 
Table 1. Dietary formulation and proximate composition of basal diet

\begin{tabular}{|c|c|}
\hline Ingredients ( $\mathrm{g} / 100 \mathrm{~g}$ diet) & Composition (\%) \\
\hline Fish meal & 57.0 \\
\hline Wheat flour & 20.0 \\
\hline Soy bean oil & 5.7 \\
\hline Fish oil ${ }^{a}$ & 5.3 \\
\hline Mineral premix ${ }^{c}$ & 2.5 \\
\hline Vitamin premix ${ }^{d}$ & 3.0 \\
\hline Cellulose $^{b}$ & 2.5 \\
\hline Binder & 2.0 \\
\hline Antifungal & 0.3 \\
\hline Antioxidant & 0.35 \\
\hline \multicolumn{2}{|l|}{ Proximate composition (\%) } \\
\hline Crude protein & 39.48 \\
\hline Crude Lipid & 19.7 \\
\hline Ash & 9.7 \\
\hline Fiber & 2.7 \\
\hline Moisture & 8.2 \\
\hline NFE & 17.9 \\
\hline Gross energy (MJ/kg) & 22.06 \\
\hline \multicolumn{2}{|l|}{$\begin{array}{l}\text { a E-Wha oil, Pusan, Korea } \\
\text { b United States Biochemic }\end{array}$} \\
\hline \multicolumn{2}{|c|}{$\begin{array}{l}{ }^{2} \text { Premix }(\mathrm{g} / 100 \mathrm{~g}) \text { contains } \mathrm{DL} \text {-calcium pantothenate, } 0.5 \text {; choline bitartrate, } 10 \text {; inositol, } 0.5 \text {; } \\
\text { menadione, } 0.02 ; \text { niacin, } 0.5 ; \text { pyridoxine- } \mathrm{HCl}, 0.1 ; \text { riboflavin, } 0.1 \text {; thiamine mononitrate, } 0.1 ; \mathrm{DL}- \\
\text { a-tocopheryl acetate, } 0.2 ; \text { retinyl acetate, } 0.02 ; \text { biotin, } 0.01 ; \text { folic acid, } 0.02 ; \mathrm{B} 12,0.0002 ; \\
\text { Cholecalciferol, } 0.008 ; \text { a-cellulose, } 85.0 \text {. }\end{array}$} \\
\hline f Gross energy $(\mathrm{MJ} / \mathrm{kg})$ calc & g to $23.6 \mathrm{~kJ} / \mathrm{g}$ for protein, $39.5 \mathrm{~kJ} / \mathrm{g}$ for lipid and17.0 \\
\hline
\end{tabular}

Experimental diet. To prepare probiotic (B. amyloliquefaciens) JFP2 enriched diets, the required amount of probiotics bacterial suspension was slowly sprayed into the feed, mixing part by part in a drum mixer, after which it was air-dried at $18^{\circ} \mathrm{C}$ under sterile conditions for $12 \mathrm{~h}$. The viability of the incorporated bacterial cells in the feed was assessed by spreading onto MRS agar (Merck). The colony count was taken after incubation at $30^{\circ} \mathrm{C}$ for $48 \mathrm{~h}$. The bacterial count of the feed taken at this point twice during the trial averaged to $1.4 \times 10^{6} \mathrm{CFU} / \mathrm{g}$. The pellets were dried in an oven at $30^{\circ} \mathrm{C}$ for $18 \mathrm{~h}$, packed and stored in a freezer at $-20^{\circ} \mathrm{C}$ until used.

Experimental design. To study the hematological and innate immune parameters, fish were randomly grouped into two treatments: control and probiotic, with three replicates of each; 35 fish in each group. Five fish were sampled every two weeks to assess blood biochemical and immune parameters. After seventy days of feeding the experimental diets, fish were challenged with S. iniae and mortality was recorded for 20 subsequent days.

Growth performance. All fish were deprived of food $24 \mathrm{~h}$ before weighing and sampling, and the following parameters were measured at the end of feeding trial ( 8 weeks):

Weight gain $=W_{2}(g)-W_{1}(g)$; Specific growth rate $(S G R)=100\left(\ln W_{2}-\ln W_{1}\right) T^{1}$; Feed conversion ratio $(F C R)=$ feed intake/weight gain $(\mathrm{g})$; Survival rate $=$ (final amount of fish/initial amount of fish) $\times 100$; Where $W 1$ is the initial weight, W2 is the final weight and $\mathrm{T}$ is the number of days in the feeding period.

Hematological and biochemical analysis. Before the experiment and after being fasted for 24 hours, five fish were randomly collected from each replicate diet group, weighed and bled with 24-G needles (Houston, 1990) for hematological, biochemical, and immunological assays. White and red blood cells (WBC: $10^{4} \mathrm{~mm}^{-3}$ and RBC: $10^{6}$ $\mathrm{mm}^{-3}$ ) were counted with a hemocytometer using Dacie's diluting fluid (Blaxhall and Daisley, 1973). Hematocrit ( $\mathrm{Ht}$ : \%) was determined using a microhematocrit reader (Compur M1100, Lab-Center, Madrid, Spain) and the values expressed as the 
percentage of erythrocytes. Hemoglobin ( $\mathrm{Hb}: \mathrm{g} / \mathrm{dl}$ ) concentration was estimated by spectrophotometry at $540 \mathrm{~nm}$ using the cyanmethemoglobin method with Drabkin's reagent (Blaxhall and Daisley, 1973). Differential leukocytes were counted from one or more blood slides of each experimental group. The leukocytes from each slide were enumerated accurately under a 400x microscope avoiding re-counting fields not less 100 cell counts. Leukocytes were identified as lymphocytes (LYM), monocytes (MON), eosinophils (EOS), and neutrophils (NEU) following Houston's method (Houston, 1990). After reading the $\mathrm{Ht}$, the packed erythrocytes were discarded and the plasma stored at $-12^{\circ} \mathrm{C}$ for biochemical analyses that included total protein (TP: $\mathrm{g} / \mathrm{dl}$ ), glucose (GLU: $\mathrm{mg} / \mathrm{dl}$ ), triglyceride, total cholesterol, aspartate aminotransferase (AST), and alanine aminotransaminase (ALT) by spectrophotometry in an automatic blood analyzer (Ch100 plus, DaeKwang Meditech, Korea).

Macrophage activity analysis. The intracellular macrophage activity (respiratory burst activity) was measured (Secombes and Fletcher, 1992) in the peripheral blood leucocytes $\left(1 \times 10^{6}\right.$ cells/well) incubated with $25 \mu \mathrm{L}$ of nitroblue tetrazolium (NBT, $1 \mathrm{~g} / \mathrm{L}$ ) in $175 \mu \mathrm{L}$ culture medium for $2 \mathrm{~h}$ at $28^{\circ} \mathrm{C}$. The supernatants were removed and the cells were fixed with $100 \%(\mathrm{v} / \mathrm{v})$ methanol for $5 \mathrm{~min}$. Each well was washed twice with $125 \mu \mathrm{L}$ of $70 \%(\mathrm{v} / \mathrm{v})$ methanol. The fixed cells were allowed to air dry. The reduced NBT (in the form of formazan) was dissolved using $125 \mu \mathrm{L}$ of $2 \mathrm{~N}$ potassium hydroxide and $150 \mu \mathrm{L}$ of dimethyl sulphoxide/well. Optical density was measured by spectrophotometry at $650 \mathrm{~nm}$.

Serum lysozyme analysis. Serum lysozyme activity was measured in combination with the microplate adaptation. In this turbidimetric assay, $0.03 \%$ lyophilized Micrococcus lysodeikticus (0.05M sodiumphosphate buffer, $\mathrm{pH} 6.2$ ) was used as a substrate. $10 \mu \mathrm{L}$ of fish serum were added to $250 \mu \mathrm{L}$ of a bacterial suspension in a ' $U$ '-bottom microtitre plate. The reduction was measured with a microplate reader (Biorad, Ramsey, MN, USA) at $22^{\circ} \mathrm{C}$ and $490 \mathrm{~nm}$ after 0.5 and $4.5 \mathrm{~min}$ of incubation. One unit of lysozyme activity was defined as a reduction in absorbance of $0.001 / \mathrm{min}$.

Challenge test. Streptococcus iniae (ATCC29178) was obtained from the Korean Type Culture Collection and was cultured in tryptic soy broth (TSB, Korea) at $25^{\circ} \mathrm{C}$ for $48 \mathrm{~h}$. After 70 days of feeding with probiotic and control diet, triplicate samples of fish 10 fish from each group were challenged by intraperitoneal injection (IP) with $0.1 \mathrm{~mL}$ of S. iniae in $0.9 \%(\mathrm{w} / \mathrm{v})$ saline containing $1.2 \times 10^{6} \mathrm{cells} / \mathrm{ml}$. All fish were kept under observation for 20 days to record any abnormal behavior, clinical signs and mortality. At the end of the challenge test, the cumulative mortality rate (\%) was calculated.

Statistical analysis. All the tests were performed in triplicate. The data were subjected to statistical analysis using the SPSS software version no. 18 (SPSS Inc., Chicago, IL, USA). The statistical analysis was done by using one-way analysis of variance (ANOVA) followed by Tukey's test to compare the means between individual treatments. $P$-value of $<0.05$ was considered significant.

\section{Results}

Growth performance and survival rate of both treatment groups of fish (control and probiotic feed) are shown in Table 2 and Fig 1 . In the probiotic fed fish group FCR

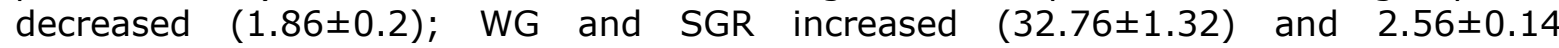
respectively) compared to the control fish group.

Table 2. Growth performance of Oplegnathus fasciatus fed with diets enriched $B$. amyloliquefacens JFP2 for 70 days*.

\begin{tabular}{lll}
\hline Index & Control diet group & Probiotic diet group \\
\hline WG & $23.16 \pm 1.14^{\mathrm{a}}$ & $32.76 \pm 1.32^{\mathrm{b}}$ \\
SGR & $2.22 \pm 0.09^{\mathrm{a}}$ & $2.56 \pm 0.14^{\mathrm{b}}$ \\
FCR & $2.18 \pm 0.22^{\mathrm{c}}$ & $1.86 \pm 0.20^{\mathrm{a}}$ \\
\hline
\end{tabular}

*Data are presented as mean \pm S.D $(n=10)$. Values in each row with different superscripts shows significant difference $(P<0.05)$. WG, weight gain; SGR, specific growth rate; FCR, fed conversion ratio 


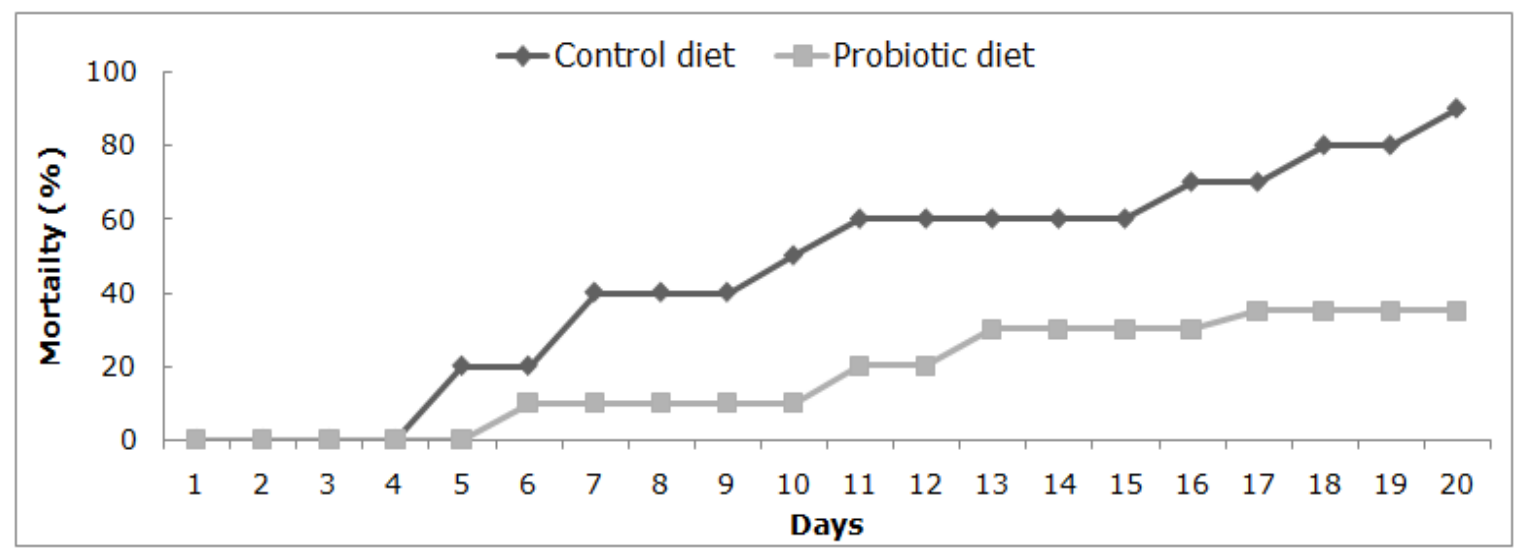

Fig.1. Cumulative mortality of Oplegnathus fasciatus fed with control and $B$. amyloliquefaciens JFP2 enriched probiotic diet. Values are mean \pm SE $(n=10)$.

Rock bream fed an $B$. amyloliquefaciens enriched probiotic diet showed a significantly $(P<0.05)$ elevated level of RBC $(0.92 \pm 0.18)$ and WBC $(12.2 \pm 0.7)$ compared to the control (Table 3$)$. There was no significant variation in $\mathrm{Hb}$ and $\mathrm{Ht}$ levels $(P>0.05)$ between control and probiotic diet fed fish groups.

Table 3. Hematological indices of Oplegnathus fasciatus fed with diets enriched $B$. amyloliquefacens -JFP-2 for 70 days*.

\begin{tabular}{lcc}
\hline Parameter & Control diet group & Probiotic diet group \\
\hline RBC $\left(10^{6} \mathrm{~mm}^{-3}\right)$ & $0.83 \pm 0.12^{\mathrm{a}}$ & $0.92 \pm 0.18^{\mathrm{b}}$ \\
WBC $\left(10^{3} \mathrm{~mm}^{-3}\right)$ & $11.7 \pm 0.5^{\mathrm{a}}$ & $12.2 \pm 0.7^{\mathrm{b}}$ \\
$\mathrm{Ht}(\%)$ & $21.1 \pm 1.2^{\mathrm{a}}$ & $21.5 \pm 1.9^{\mathrm{a}}$ \\
$\mathrm{Hb}(\mathrm{g} \mathrm{dL}-1)$ & $5.64 \pm 0.24^{\mathrm{a}}$ & $5.52 \pm 0.58^{\mathrm{a}}$ \\
Lymphocytes $(\%)$ & $80.8 \pm 1.26^{\mathrm{a}}$ & $77.8 \pm 1.32^{\mathrm{b}}$ \\
Neutrophils $(\%)$ & $16.9 \pm 0.9^{\mathrm{a}}$ & $19.4 \pm 1.0^{\mathrm{b}}$ \\
Monocyte $(\%)$ & $0.87 \pm 0.10$ & $1.14 \pm 0.18$ \\
Eosinophils $(\%)$ & $0.34 \pm 0.07$ & $0.37 \pm 0.08$ \\
\hline
\end{tabular}

*Data are presented as mean \pm S.D $(n=5)$. Data in the same row with different superscript are significantly different $(P<0.05)$. RBC- red blood cells; WBC- white blood cells; Hb- hematocrit; Hb-haemoglobin concentration.

Probiotic diet fish group showed significant decrease in cholesterol and triglyceride levels compared to the control diet fish (Fig. 2). Conversely, total protein and glucose level rose significantly $(P<0.05)$ (Fig 3 ) while the two liver enzymes namely ALT and AST decreased significantly (Fig. 4) in the probiotic diet group when compared to control diet group. Among the innate immune parameters, respiratory burst and lysozyme activity were found to rise significantly $(P<0.05)$ in the fish fed probiotic feed compared to the control (Fig. 5). 

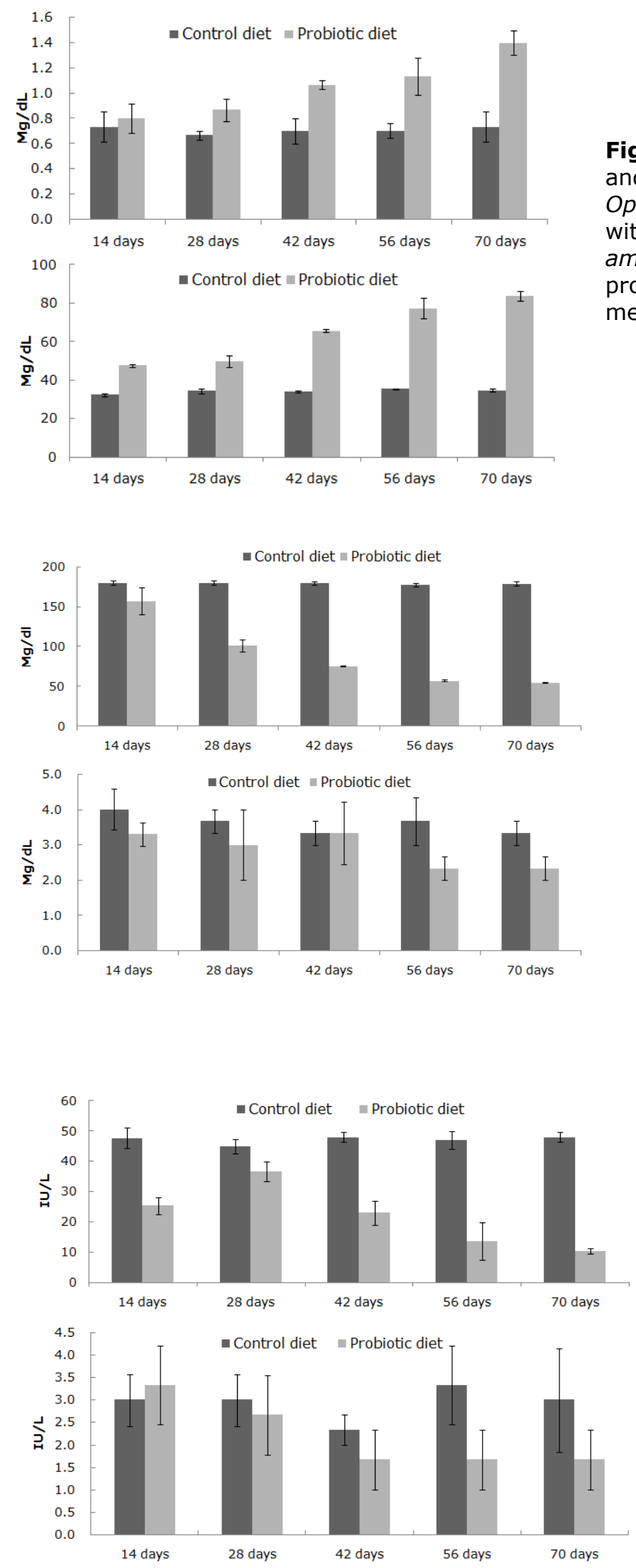

Fig. 2. Serum total protein and glucose levels of Oplegnathus fasciatus fed with control and $B$. amyloliquefaciens enriched probiotic diet. Values are mean $\pm \operatorname{SE}(n=5)$.
Fig. 3. Serum cholesterol and triglycerides levels of Oplegnathus fasciatus fed with control and $B$. amyloliquefaciens enriched probiotic diet. Values are mean $\pm S E(n=5)$.
Fig. 4. Serum aspartate aminotransferase (AST) and alanine amino-transferase (ALT) levels of Oplegnathus fasciatus fed with control and $B$. amyloliquefaciens enriched probiotic diet. Values are mean $\pm \operatorname{SE}(n=5)$. 

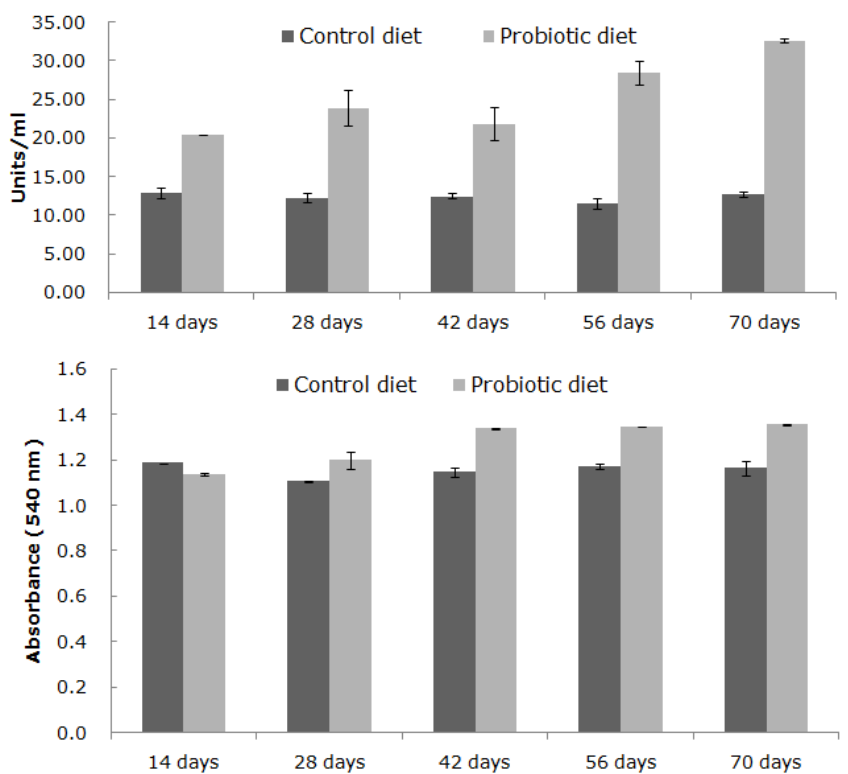

Fig. 5. Serum lysozyme and respiratory burst activity of Oplegnathus fasciatus fed with control and $B$. amyloliquefaciens enriched probiotic diet. Values are mean $\pm S E(n=5)$.

\section{Discussion}

Dietary effect of our lab isolated probiotic bacterial strain Bacillus amyloliquefacensJFP2 from Jeju Island's traditional fermented seafood, jeotgal was assessed for growth and innate immune parameters of rockbream, Oplegnathus fasciatus.

Growth and survival rate. Fish fed probiotic enriched feed showed significant increase in growth, FCR and survival rate compared to control diet fed fish. Similarly, significant effects of probiotic enriched diet on growth performance have also been reported in red sea bream (Dawood et al., 2016), rohu (Ghosh et al., 2003), Nile tilapia (Aly et al., 2008), Siberian sturgeon (Pourgholam et al., 2016) and Pla Pho (Pangasius bocourti) (Meng-Umphan, 2009).

Hematological and blood biochemical parameters. Generally hematological parameters of fish are reported to be influenced by several factors such as species, size, age, physiological status, culture conditions and the dietary regime. In the present study, a $B$. amyloliquefaciens-JFP2 enriched probiotic diet significantly $(P<0.05)$ enhanced RBC and WBC levels and there was no variation in $\mathrm{Hb}$ and $\mathrm{Ht}$ levels between control and probiotic diet fed fish groups. The amounts of hemoglobin and hematocrit are a function of RBC changes (Soltanzadeh et al., 2015). Previous studies have also reported that fish fed with feed enriched with probiotic species such as Bacillus licheniformis, B. subtilis, Saccharomyces cerevisiae etc show increased WBC and RBC levels and the cellular innate immune response is enhanced (Kumar et al., 2013; Kumar et al., 2006; Jessus et al., 2002).

B. amyloliquefaciens enriched probiotic diet fed fish show a significant decrease in cholesterol and triglyceride levels compared to the control diet fed fish (Fig. 2). Similar declining pattern of triglycerides and total serum cholesterol levels were reported in tilapia fed with feed containing Bacillus cereus (Wang et al., 2015). However, levels of total protein and glucose rose significantly $(P<0.05)$ in probiotic fed fish compared to the control diet fed fish (Fig. 3). Likewise increased glucose levels were reported in Rogu, Labeo rohita and Nile tilapia, Oreochromis niloticus when fed diets enriched with probiotic bacteria (Mohapatra et al., 2014; Reda and Selim, 2015). In general, an increase in serum protein level is an indicator of innate immunity, which is considered important in invertebrates and a fundamental defense mechanism of fish (Ellis, 1990). Such mechanisms form a series of essential functions that keep host cells alive, healthy, and protected from pathogens. The use of Bacillus species has been shown to elicit inhibitory responses to numerous fish diseases, such as red mouth disease, edwardsiellosis, furunculosis, lactococcusis, streptococcusis, vibriosis and aeromoniasis (Harikrishnan et al., 2010; Brunt et al., 2007; Ridha et al., 2003; Kumar et al., 2006; Taoka et al., 2006; Kamgar et al., 2012 ). 
ALT and AST, two liver enzymes, decreased in the probiotic diet fish group compared to the control (Fig. 4). Results indicate that probiotic diet could decrease the level of liver enzymes. This is in accordance with the results of Lin and Luo, (2011).

Innate immune factors. Among the innate immune parameters, respiratory burst and Iysozyme activity were found to rise significantly $(P<0.05)$ in the fish fed with probiotic feed compared to the control (Fig. 5). Similar results were observed after feeding diets formulated with probiotic bacteria in rogu and mrigala (Mohapatra et al., 2014; Bandyopadhyay, et al., 2015). Respiratory burst activity due to an increase in the oxidation level in phagocytes stimulated by foreign agents is considered to be an important indicator of innate defense mechanism in fish (Miyazaki, 1998), where $\mathrm{O}_{2}^{-}$is the first product to be released (Lee et al., 2000). In fish the $\mathrm{O}_{2}{ }^{-}$production is generally affected after activation of phagocytes since it triggers production of superoxide anion $\left(\mathrm{O}_{2}{ }^{-}\right)$and its reactive derivatives (i.e. hydrogen peroxide and hydroxyl radicals) associated with intense oxygen consumption, called the respiratory burst (Secombes and Fletcher, 1992). The reactive species are capable of destroying the invading pathogens (Hassett and Cohen, 1989). In the present study, administration of probiotic enhanced diet improved the production of ROS and RNS by peripheral blood leucocytes and oxygen radicals during the process of oxidative burst from week 1-6. Production of ROS and RNS or NO is a crucial mechanism limiting the growth of fish pathogens (Olivier et al., 1985).

The enhancement of the innate immune response with a $B$. amyloliquefaciens enriched probiotic diet, decreased mortality rate (Fig. 1) thereby protecting the fish against $S$. iniae. In addition, feed utilization increases thereby decreasing the amount of feed necessary for fish growth, and thus reducing production costs. Our results suggest that the dietary inclusion of probiotic bacterial stain Bacillus amyloliquefacens-JFP-2 isolated from jeogtal, improves the growth and health status of rockbream, Oplegnathus fasciatus challenged with S. iniae.

\section{Acknowledgements}

The authors are grateful to the National Research Foundation of Korea (NRF) for grants funded by the Leading Human Resource Training Program of Regional Neo industry through the Ministry of Science, ICT and Future planning (2016H1D5A1911152).

\section{References}

Abdel-Tawwab M., Abdel-Rahman A.M. and N.E. Ismael, 2008. Evaluation of commercial live bakers' yeast, Saccharomyces cerevisiae as a growth and immunity promoter for Fry Nile tilapia, Oreochromis niloticus (L.) challenged in situ with Aeromonas hydrophila. Aquaculture, 280:185-189.

Aly S.M., Ahmed Y.A.G., Ghareeb A.A.A. and M.F. Mohamed, 2008. Studies on Bacillus subtilis and Lactobacillus acidophilus, as potential probiotics, on the immune response and resistance of Tilapia nilotica (Oreochromis niloticus) to challenge infections. Fish Shellfish Immunol., 25:128-136.

Aly S.M., Mohamed M.F. and G. John, 2008. Effect of probiotics on the survival, growth and challenge infection in Tilapia nilotica (Oreochromis niloticus), Aquacult Res., 39:647-656.

Bandyopadhyay, P., Sarkar, B., Mahanty, A., Rathore R.M. and B.C. Patra, 2015. Dietary Administered Bacillus sp. PP9 Enhances Growth, Nutrition and Immunity in Cirrhinus mrigala (Hamilton). Proc. Natl. Acad. Sci., India, Sect. B Biol. Sci., 85:759.

Bansemir A., Blume M., Schroder S. and U. Lindequist, 2006. Screening of cultivated seaweeds for antibacterial activity against fish pathogenic bacteria. Aquaculture, 252:79-84.

Blaxhall, P.C. and K.E. Daisley, 1973. Routine haematological methods for use with fish blood. Fish Biol., 5:771-781.

Brunt J., Newaj-Fyzul A. and B. Austin, 2007. The development of probiotics for the control of multiple bacterial diseases of rainbow trout, Oncorhynchus mykiss (Walbaum), J. Fish Dis., 30:573-579. 
Dawood M.A.O. and S. Koshio, 2016. Recent advances in the role of probiotics and probiotics in carp aquaculture: A review. Aquaculture. 454:243-251.

Ellis A.E., 1990. In: Stolen J.S., Fletcher T.C., Anderson D.P., Robertson B.S., VanMuisvinkel W.R., editors. Lysozyme assay in techniques in fish immunology. Fair Haven, NJ, USA: SOS Publications pp101-103.

FAO, 2014. The State of World Fisheries and Aquaculture 2014. Fisheries and Aquaculture Department, FAO, Rome.

Ghosh K., Sen S.K. and A.K. Ray, 2003. Supplementation of an isolated fish gut bacterium, Bacillus circulans, in formulated diets for rohu, Labeo rohita, fingerlings. Isr. J. Aquacult.-Bamidgeh, 55:13-21.

Gullian M., Thompson F. and J. Rodriguez, 2004. Selection of probiotic bacteria and study of their immunostimulatory effect in Penaeus vannamei, Aquaculture, 233:1-14.

Harikrishnan R., Balasundaram C. and M.-S. Heo, 2010. Lactobacillus sakei BK19 enriched diet enhances the immunity status and disease resistance to streptococcosis infection in kelp grouper, Epinephelus bruneus. Fish Shellfish Immunol., 29:1037-1043.

Hassett D.J. and M.S. Cohen, 1989. Bacterial adoption to oxidative stress: implications of pathogenesis and interaction with phagocytic cells. Federation Am. Soc. Expt. Biol., 3:1574-81.

Houston A.H., 1990. Blood and circulation. C.B. Schreck, P.B. Moyle (Eds.), Methods for fish biology, American Fisheries Society, Maryland.

Hwang U.G., Lee J.S. and J.C. Kang, 2013. Responses of the hepatic microsomal cytochrome P450 monooxygenase system in rock bream Oplegnathus fasciatus exposed to tributyltin (TBT). Fish Aquat. Sci., 16:261-265.

Jessus Ortuno, Alberto Cuesta, Alejandro Rodriguez, Angeles Eesteban M. and Jose Meseguer, 2002. Oral administration of yeast, Saccharomyces cerevisiae, enhances the cellular innate immune response of gillhead seabream, Sparusaurata L. J. Vet immunol immunopathol., 85:41-50.

Kamgar M. and M. Ghane, 2012. Evaluation of Bacillus subtilis effect as probiotic on Hematological parameters of rainbow Trout, Oncorhynchus mykiss (INaIbaum) following experimental infection with Streptococcus iniae, J. Fish Aquat. Sci., 7:422430.

Kang Y.J., Lee S.M., Hwang H.K. and S.C. Bai, 1998. Optimum dietary protein and lipid levels on growth in parrot fish (Oplegnathus fasciatus). Kor. J. Aquat. Sci., 11:110

Kim K.M., Lee J.U., Kim J.W., Han S.J., Kim K.D. and J.Y. Jo, 2008. Daily feeding rates of parrot fish Oplegnathus fasciatus fed extruded pellet at the different water temperatures. Kor. J. Aquat. Sci., 21:294-298.

Kim J.H., Jeong D.S. and J.C. Kang, 2013. Toxic effects on the nonspecific immune system of the rock bream Oplegnathus fasciatus upon exposure to di-2-ethylhexyl phthalate. Fish Aquat. Sci., 16:171-176.

Ko G.Y., Lim S.J., Kim S.S., Oh D.H. and K.J. Lee, 2008. Effects of dietary supplementation of Scoria on growth and protein digestibility in juvenile parrot fish Oplegnathus fasciatus and olive flounder Paralichthys olivaceus. Aquaculture, 21:133138.

Kumar R., Mukherjee S.C., Prasad K.P. and A.K. Pal, 2006. Evaluation of Bacillus subtilis as a probiotic to Indian major carp Labeo rohita (Ham.). Aquaculture Res., 37:1215-1221.

Kumar N.R., Raman R.P., Jadhao S.B., Brahmchari R.K., Kumar K. and G. Dash, 2013. Effect of dietary supplementation of Bacillus licheniformis on gut microbiota, growth and immune response in giant freshwater prawn, Macrobrachium rosenbergii (de Man, 1879). Aquacult Int., 21:387-403.

Lee D., Rieman C.B.E. and W. Thompson, 2000. Bayesian viability assessment module (BayVAM): a tool for investigating population dynamics and relative viability of resident and anadromous salmonids. USDA Forest Service, Boise, ID.

Lim S.J., Oh D.H., Khosravi S., Cha J.H., Park S.H., Kim K.W. and K.J. Lee, 2013. Taurine is an essential nutrient for juvenile parrot fish Oplegnathus fasciatus. Aquaculture, 414/415:274-279. 
Lin S. and L. Luo, 2011. Effects of different levels of soybean meal inclusion in replacement for fish meal on growth, digestive enzymes and transaminase activities in practical diets for juvenile tilapia, Oreochromis niloticus $\times 0$. aureus. Anim. Feed Sci. Technol., 168(1):80-87

Mayra-Makien, A. and M. Bigret, 1993. Industrial Use and Production of Lactic Acid Bacteria. In: Lactic Acid Bacteria, Salminen, S.V. and A. Wright (Eds.). Marcel Dekker, New York, pp: 65.

Meng-Umphan K., 2009. Growth performance, sex hormone levels and maturation ability of Pla Pho (Pangasius bocourti) fed with Spirulina supplementary pellet and hormone application. Int. J. Agric. Biol., 11:458-462.

Miao Ling-Hong, Ren Ming-Chun, Ge Xian-Ping, Xie Jun, Zhu Jian, Liu Bo, Zhou Qun-Lan, Pan Liang-Kun, 2016. Utilization and Metabolism of a-Starch by Black Carp (Mylopharyngodon piceus) Juveniles, 10 pages. Isr. J. Aquacult.-Bamidgeh, 68.2016.1259.

Miyazaki T., 1998. A simple method to evaluate respiratory activity of blood phagocytes from Japanese flounder. Fish Pathol., 33:141-142.

Mohapatra S., Chakraborty T., Prusty A.K., PaniPrasad K. and K.N. Mohanta, 2014. Beneficial Effects of Dietary Probiotics Mixture on Hemato-Immunology and Cell Apoptosis of Labeo rohita Fingerlings Reared at Higher Water Temperatures. PLoS ONE, 9(6):e100929.

MOMAF. 2014. Statistical database for fisheries production [Internet]. Korea National Statistical Office, Daejeon, Korea. Accessed 26 June 2016, http://www.fips.go.kr.

Nayak S., 2010. Probiotics and immunity: a fish perspective. Fish Shellfish Immunol. 29:2-14.

Nwanna, L.C, Ajani E.K. and Bamidele S.F., 2014. Use of Lactic Acid Bacteria from Nile tilapia Oreochromis niloticus as Probiotics for Sustainable Production and Improvement in Fish Welfare, 12 pages. Isr. J. Aquacult.-Bamidgeh, 66.2014.977.

Olivier G., Evelyn T.P.T. and R. Lallier, 1985. Immunity to Aeromonas salmonicida in Coho salmon (Oncorhynchus kisutch) induced by modified Freund's complete adjuvant: its nonspecific nature and the probable role of macrophages in the phenomenon. Dev. Comp. Immunol., 9:419-32.

Pal D., Joardar S.N., and Roy B., 2007, Immunostimulatory effects of a yeast (Saccharomyces cerevisiae) cell wall feed supplement on rohu (Labeo rohita), an Indian major carp. Isr. J. Aquacult.-Bamidgeh, 59(3), p175-181.

Pourgholam, M.A., Khara, H., Safari, R. et al., 2016. Dietary Administration of Lactobacillus plantarum Enhanced Growth Performance and Innate Immune Response of Siberian Sturgeon, Acipenser baerii. Probiotics \& Antimicro. Prot., 8:1.

Reda R.M and K.M. Selim, 2015. Evaluation of Bacillus amyloliquefaciens on the growth performance, intestinal morphology, hematology and body composition of Nile tilapia, Oreochromis niloticus. Aquacult Int., 23:Page 203

Ridha M.T. and I.S. Azad, 2012. Preliminary evaluation of growth performance and immune response of Nile tilapia Oreochromis niloticus supplemented with two putative probiotic bacteria, Aquacult. Res., 43:843-852.

Ridha M., Larsen J., Nielsen M.E. and K. Buchmann, 2003. Enhanced resistance of rainbow trout, Oncorhynchus mykiss (Walbaum), against Yersinia ruckeri challenge following oral administration of Bacillus subtilis and B. licheniformis (BioPlus2B), J. Fish Dis. 26:495-498.

Salminen S., Ouwehand A., Benno Y. and Y. Lee, 1999. Probiotics: how should they be defined? Trends Food Sci. Tech., 10:107-110.

Secombes C.J. and T.C. Fletcher, 1992. The role of phagocytes in the protective mechanism in fish. Annu. Rev. Fish Dis., 2:53-71.

Soltanzadeh, S., Esmaeili Fereidouni, A., Ouraji, H. et al., 2016. Growth performance, body composition, hematological, and serum biochemical responses of beluga (Huso huso) juveniles to different dietary inclusion levels of faba bean (Vicia faba) meal. Aquacult. Int., 24:395. 
Taoka Y., Maeda H., JO J.Y., Jeon M.J., Bai S.C., Lee W.J., et al., 2006. Growth, stress tolerance and non-specific immune response of Japanese flounder Paralichthys olivaceus to probiotics in a closed recirculating system, Fish Sci., 72:310-321.

Wang M., Liu G., Lu M., Ke X., Liu Z., Gao F., Cao J., Zhu H., Yi M. and D. Yu, 2016. Effect of Bacillus cereus as a water or feed additive on the gut microbiota and immunological parameters of Nile tilapia. Aquac Res. Pages 1-11.

Wang X., Kim K., Bai S.C., Huh M. and B. Cho, 2003. Effects of the different levels of dietary vitamin $\mathrm{C}$ on growth and tissue ascorbic acid changes in parrot fish (Oplegnathus fasciatus). Aquaculture, 215:203-211.

Zhou X., Tian Z., Wang Y. and W. Li, 2010. Effect of treatment with probiotics as water additives on tilapia (Oreochromis niloticus) growth performance and immune response, Fish Physiol. Biochem., 36:501-509. 